\title{
Results and Conclusions on Metallic Materials Made by AM within the Austrian Leader Project "addmanu"
}

\author{
Bruno Buchmayr ${ }^{1}$, Gerhard Panzl' ${ }^{1}$, Alexander Walzl' ${ }^{1}$, Christopher Wallis ${ }^{1}$, Reinhard Hubmann ${ }^{2}$, and \\ Michael Kitzmantel $^{3}$
}

${ }^{1}$ Chair for Metal Forming, Montanuniversität Leoben, Leoben, Austria

${ }^{2}$ FOTEC GmbH, Wiener Neustadt, Austria

${ }^{3} \mathrm{RHP}-\mathrm{Technology} \mathrm{GmbH}$, Seibersdorf, Austria

Received December 17, 2018; accepted January 20, 2019; published online February 7, 2019

\begin{abstract}
The paper provides a selection of manifold results and findings gained within a national research and leader project, called "addmanu", which has motivated a lot of other researchers and companies to go into this interesting field of metallic additive manufacturing. New material developments, lightweight AM-concepts, hybrids, components having a very complex geometry, production of very small channels, reduction of surface roughness, and the production of a series of parts in high-tech application areas are demonstrated.
\end{abstract}

Keywords: Selective laser melting (SLM), Addmanu, Metallic components, Topology optimization, Hybrids, Advanced applications

Erkenntnisse aus dem nationalen Projekt „addmanu“ über die Additive Fertigung von metallischen Werkstoffen

Zusammenfassung: In diesem Artikel wird ein Auszug der vielfältigen Ergebnisse und Erkenntnisse aus dem nationaIen Leader-Projekt „addmanu“ wiedergegeben, die viele Forscher und Unternehmen auch dazu ermuntert haben, in das interessante Gebiet der Additiven Fertigung metallischer Komponenten einzusteigen. Neue Werkstoffentwicklungen, AM-gestützter Leichtbau, Hybridanwendungen, Bauteile mit sehr komplexer Geometrie, die Fertigung von sehr engen Kühlkanälen, Maßnahmen zur Reduktion der Oberflächenrauheit und die Produktion einiger Teile für High-Tech-Anwendungen werden dargestellt.

Schlüsselwörter: Selektives Laserschmelzen (SLM), Addmanu, Metallische Komponenten,

Topologieoptimierung, Hybride, Moderne Anwendungen

B. Buchmayr ( $\triangle)$

Chair for Metal Forming,

Montanuniversität Leoben,

8700 Leoben, Austria

Bruno.Buchmayr@unileoben.ac.at

\section{Introduction}

In order to foster the market potential and to concentrate on problematic issues of additive manufacturing, an Austrian leader project was established. The project was sponsored by The Austrian Research Promotion Agency (FFG) over a period of three years with more than 20 research partners coming from universities, R\&D firms, and industry. In mid 2018 , the project called "addmanu" was successfully completed. The project structure covered aspects of design, processing, and applications of components made from metals, polymers, ceramics, and hybrids. In this paper, only metallic systems are considered, with special emphasis on new powder materials, hybrids, topology optimization and joints between dissimilar materials, fabrication of small channels and surface modifications. Regarding potential application fields, demonstrator examples for mechanical engineering, tools for injection moulding, lightweight automotive components, nozzles for aerospace technology, and composites with special properties for satellites are shown. Basics, classifications, process descriptions, economical aspects, and typical applications are not considered in this paper but can be found in the available literature [1-10].

\section{Structure of Leader Project "addmanu"}

The main structure, working packages, and location of scientific and industrial partners are shown in Fig. 1. The main objectives were focussed on the development of new AMmaterials, modelling, and simulation of new industrial processing types, on the analysis of requirements and process-oriented design rules as well as on process integration and new business models. The definitions of the working packages (WPs) were based on a SWOT-analysis [11] on AM- and SLM-technology, respectively. The project was aligned to strengthen the value-added chain from produc- 


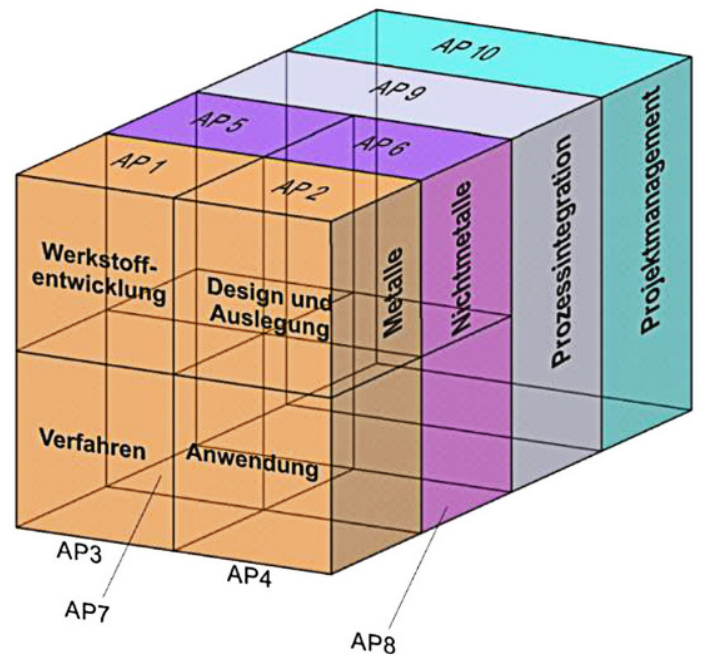

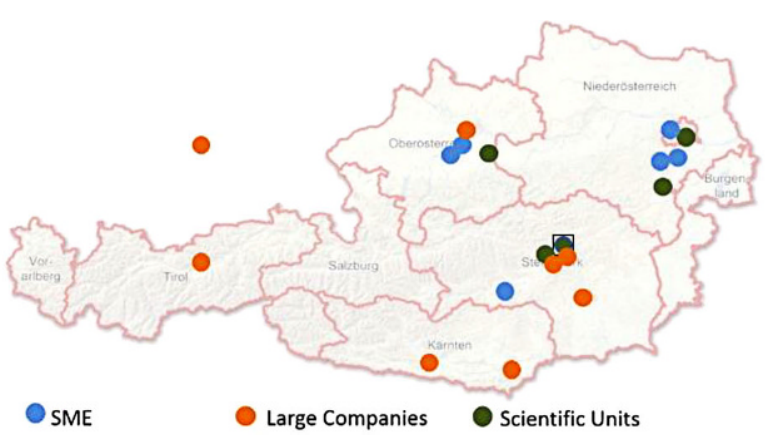

(1) R\&D and Education: Joanneum Research, FOTEC, Montanuniversität Leoben, Profactor, TU Wien (2) materials/surface engineering: Böhler Edelstahl, RHI,

(3) Mechanical engineering and tool making: Hage, PKT, Lithoz Vienna (4) Electronics: LAM Research

(5) Automotive: Magna Steyr Engineering, Mahle Austria Filter systems

(6) Aerospace: Airbus DS, RHP Technology

(7) Energy technology: GE Jenbacher

Fig. 1: Structure and working packages of leader project "addmanu”

Fig. 2: Processing map for selective laser melting of metallic powders [12]

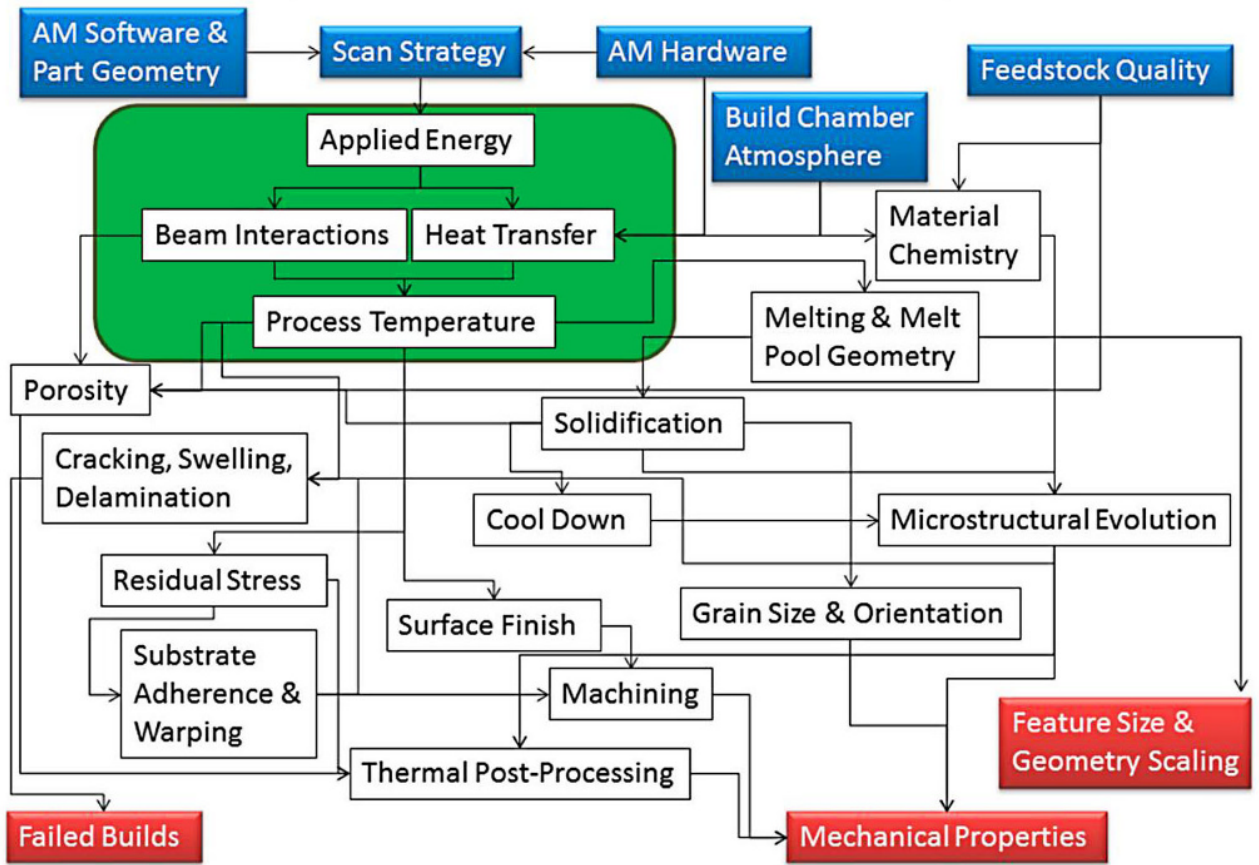

tion of power material to typical application areas like automotive, aeronautics, tool making, electronics, and hightemperature materials. WP5 to WP8 concentrated on nonmetallic materials, i.e. mainly ceramics and polymers, using processes like stereo-lithography or the FDM process. In the following, the objectives and findings in the WPs are described in detail.

A typical knowledge map for the use of selective laser melting is shown in Fig. 2 [12], which makes the manifold issues and complex interrelations visible. Material aspects, like laser weldability, powder characterisation, selection of proper process parameters, AM-oriented design, consideration of residual stresses or distortion, and the optimization of almost 100 processing parameters can only be per- formed within a well-balanced consortium as was provided in "addmanu".

\section{New Metallic Materials and Hybrids Made by SLM}

The objective in WP1 was the development of newly advanced SLM-powders for use in injection moulding dies. The high-alloyed powders were designed to have improved service properties, like increased hardness and wear resistance, higher thermal conductivity, and better polishing properties. Much work was necessary to characterize different powder types, which was based on the guidelines provided in the guideline VDI 3405. In experimental trials with 

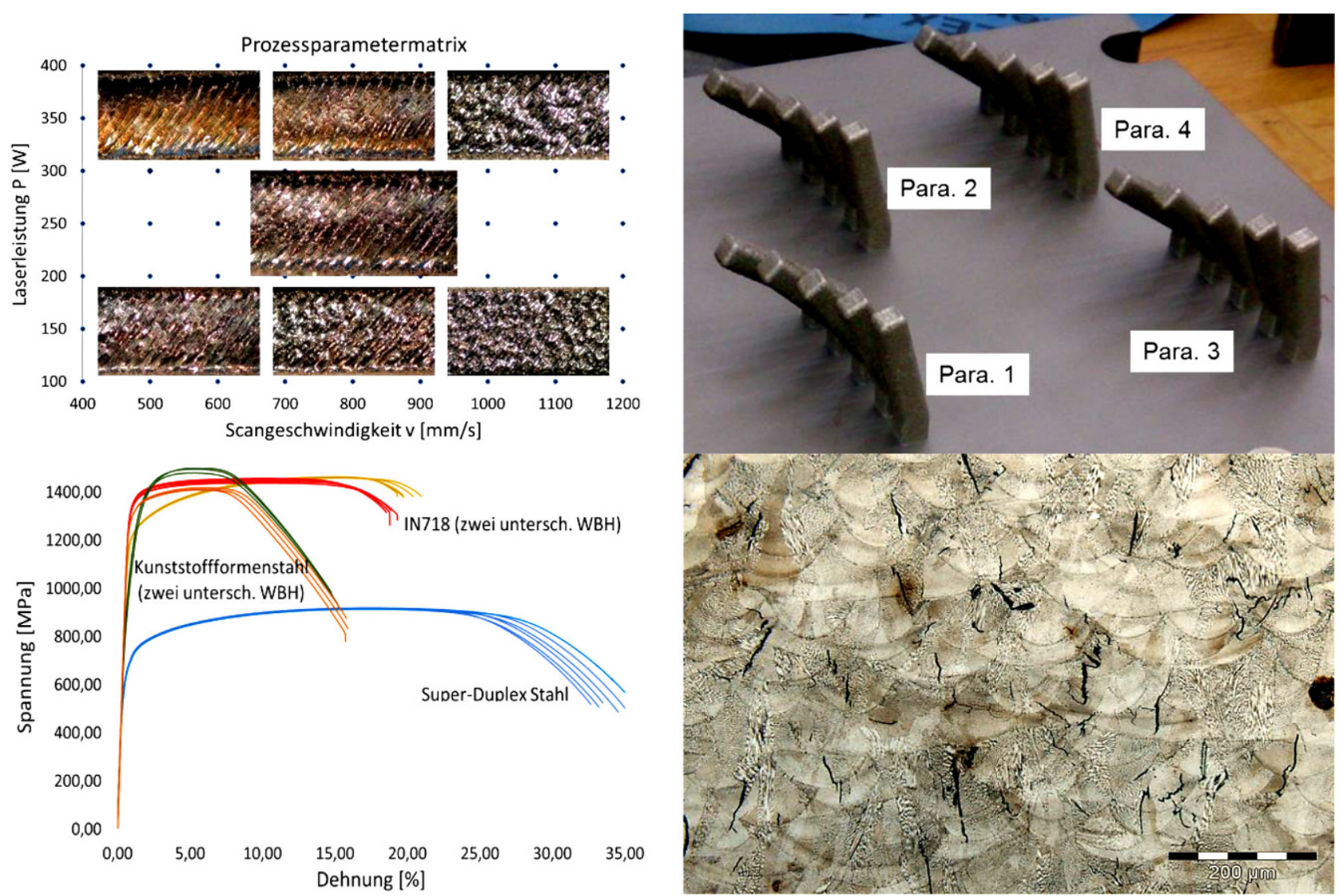

Fig. 3: Assessment procedure to find optimal AM-powders and processing parameters for use in polymer injection moulds

variations of the main process parameters laser power and scanning speed as well as hatching parameters, optimal parameter combinations were found which ensure min. relative densities of $99.5 \%$. Some typical assessments with respect to surface appearance, critical building angle, mechanical properties, and microstructure are shown in Fig. 3.

Details of this experimental work on powder development can be found in [13-15].

In a second part of this WP, new innovative hybrid structures were investigated using massive base materials like $\mathrm{AIN}, \mathrm{Al}_{2} \mathrm{O}_{3}, \mathrm{MMC}, \mathrm{Cu}$, steel, and powders of steel, $\mathrm{CuCrZr}$, $\mathrm{Al}$, and Ti. As an example for hybrid structures, Fig. 4 shows a cooling structure applied to a Cu-diamond-MMC base material. Cu sputtering was used as an intermediate layer between MMC and a maraging steel. Further details on this work can be found in [16-19].

\section{Topology and Shape Optimization of AM- Parts}

Increased requirements for lightweight design and functional integration lead to very complex geometries, which can be produced only by additive manufacturing. Using methods, like topology and shape optimization, coupled with cellular or grid structures, as discussed by Mike Ashby, very efficient lightweight components can be built. In this WP or within the doctoral thesis of A. Walzl [20-23], funda- mental analytical equations were derived, FE simulations and experimental verifications were done and modified according to the situation of AM production, taking into account processing limits and AM design guidelines. An example for topology optimization and a continuous grid structure is shown in Fig. 5. For the optimization response parameters, constraint parameters, and objective parameters have to be set. For the processing steps of CAD, mechanical FEM, Laser-Powder Bead data preparation the software packages Inventor, Hyperworks incl. Optistruct and Magics/Netfabb were used. The new calculation procedure for optimized grid structures is given in Fig. 6 .

\section{AM-Process Development for Metallic Structures}

To find out the geometrical process limits of SLM and other AM technologies, special trials were carried out to define the smallest channel diameters and very fine surface structures. The smallest diameter factor to build very fine structures was found to be about $0.3 \mathrm{~mm}$.

New electro-chemical methods for surface treatment were developed for AISi $10 \mathrm{Mg}$ and Hastelloy $\mathrm{X}$ components in order to reduce the surface roughness. Ranging from simple geometrical parts to very complex components (Fig. 7), a reduction of surface roughness from $R z=130 \mu \mathrm{m}$ down to $25 \mu \mathrm{m}$ could be achieved. 
Hier steht eine Anzeige.

글 
Hier steht eine Anzeige.

글 
Fig. 4: SLM processing used for the production of a hybride cooling device
Fig. 5: Topology-optimised automotive component (left) and a grid structure (right)
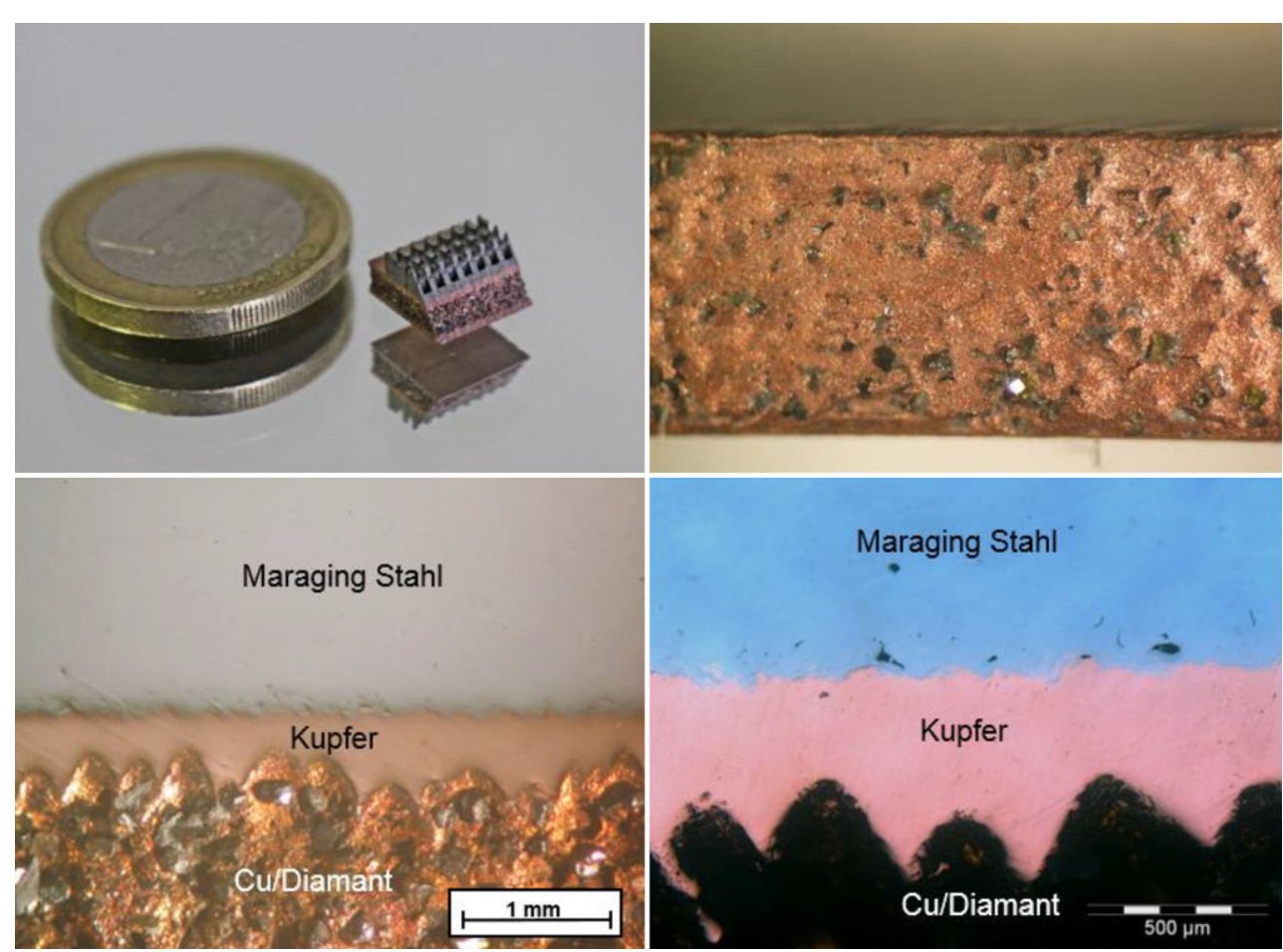
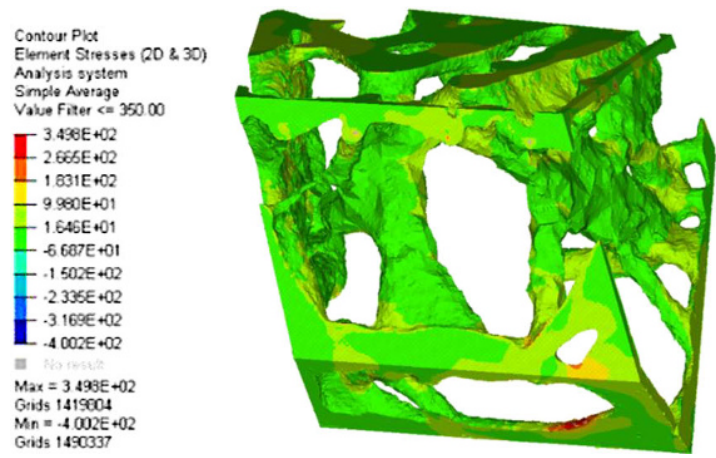

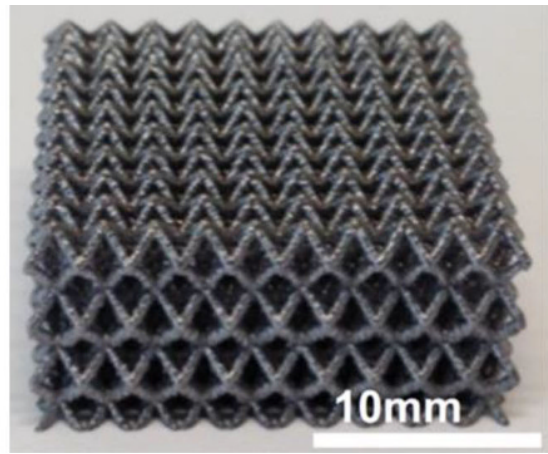

\section{New SLM-Applications of Metallic Components in Mechanical Engineering}

To gain a substantial impact for new business areas, the potential of new application areas in mechanical engineering, tool making, automotive, and aerospace were considered in WP4. An overview is provided in Fig. 8.

Several designs and prototypes for inlet nozzles for gaspowered combined heat and power units were made at GE Jenbacher using the SLM-technology. Different nickelbase alloys were used and tested in the lab as well as in gas engines. Aspects of process integration, quality assurance and component qualification were performed. The advanced procedure was also applied for other components, like precombustion chamber (Fig. 9) and cooling nozzles.

Tools for injection moulding were investigated in WP 4.2. Near surface and bionic inspired cooling channels were produced by using SLM. The optimal designs were calculated by FEM, and experimental tests were performed to measure the surface temperature (Fig. 10). Significant im- provements regarding the heat transfer could be achieved, which led to a better productivity or cycle time respectively.

For applications in aerospace, Fotec, RHP, and UT/MUL tried to build very complex components made of very expensive powder materials. Fig. 11 shows an injection nozzle/plate of the third stage of a rocket, which is made of a heat resistant nickel base alloy. In this part, fuel and oxidizer are mixed before the inlet into the combustion chamber. On the right hand side, a trial made from AISi10Mg is shown. The SLM building time was about one week, the flange diameter was about $250 \mathrm{~mm}$.

Very powerful and light components are required to build satellites. As an example, Fig. 12 shows a body for electronic components. The body needs to be cooled very efficiently. Some parts are made of AISi10Mg and some are made of Al-MMC with diamond particles in it. The cooling channels have a diameter of $1.335 \mathrm{~mm}$ and the smallest fines about $0.5 \mathrm{~mm}$. 


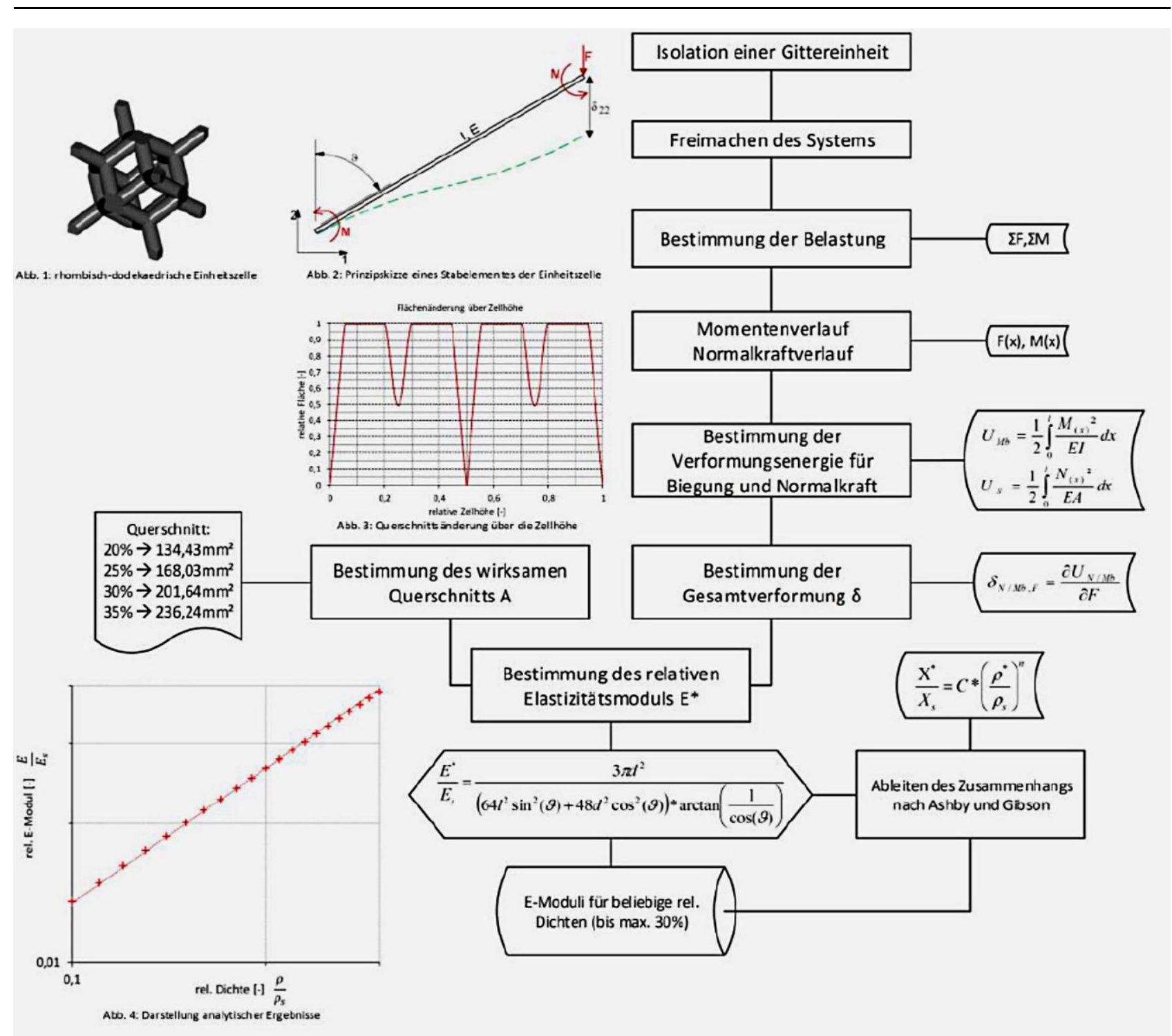

Fig. 6: Calculation procedure to optimise grid structures dependent on the loading conditions
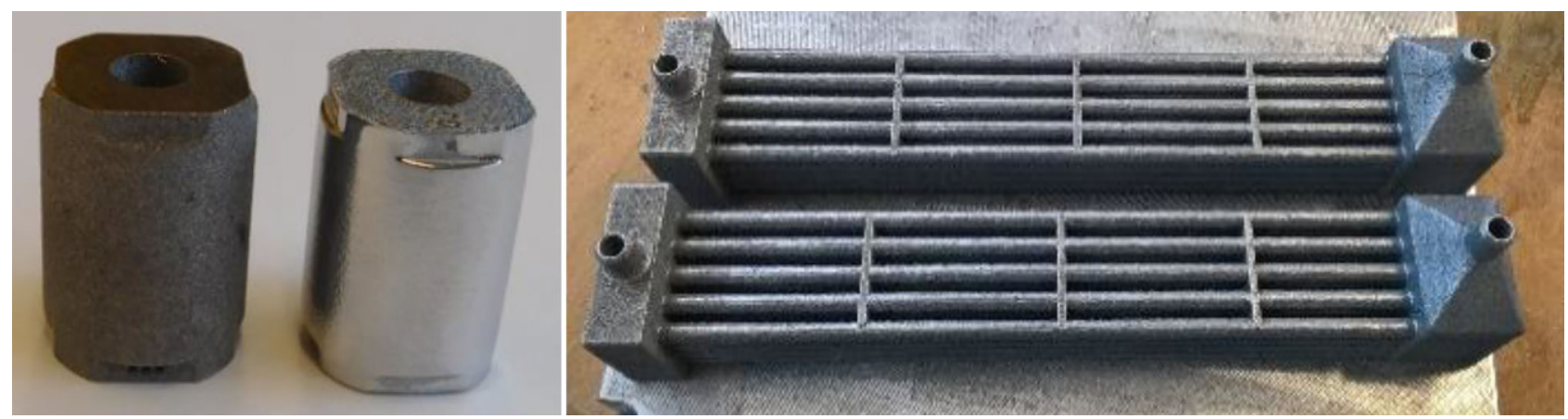

Fig. 7: Application of electro-chemical surface treatment on small and complex parts to reduzed Rz (Fotec) 
Fig. 8: Application areas (WP4) and some problem areas in mechanical engineering

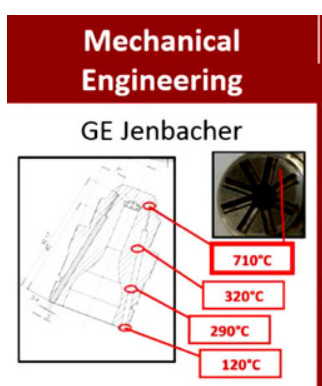

Design, thermodynamics, CFD, wear and SLM-design rules

Selection of proper Nibase materials for nozzle applications

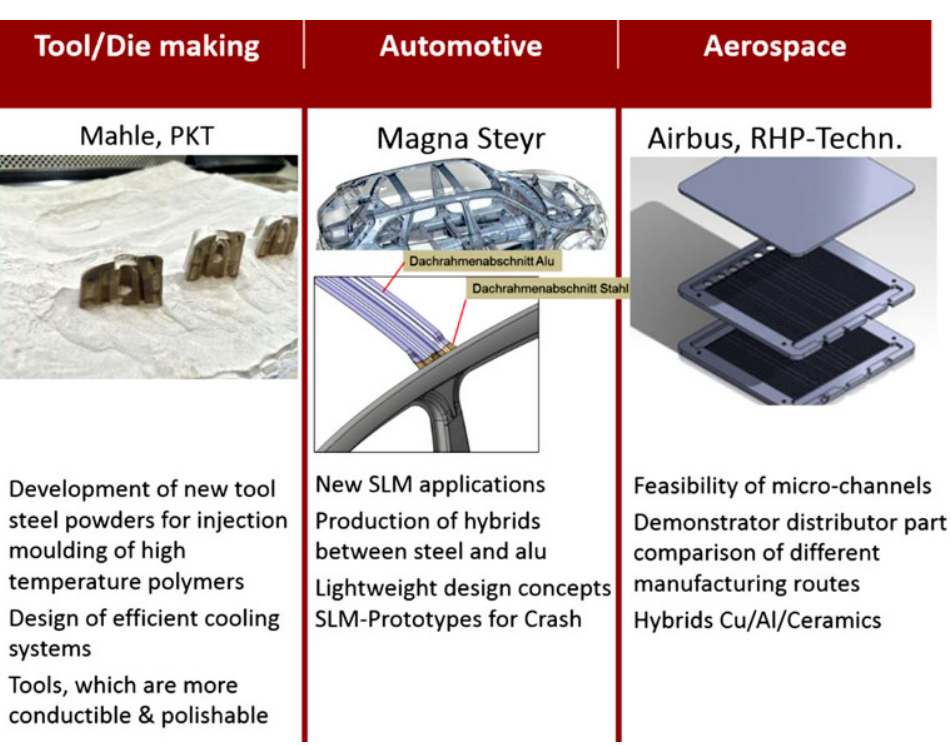

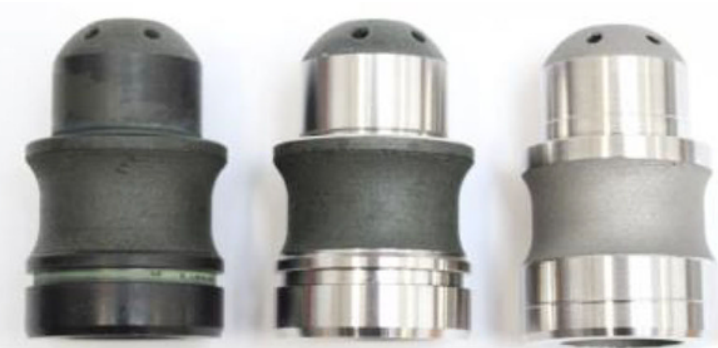

Fig. 9: Precompustion chamber-processing steps after laser welding (GE Jenbacher)

\section{Dissemination of the Results}

According to the leader project character, a very broad dissemination was aimed for from the beginning on in various forms: in almost 50 presentations at conferences and special events (e.g. Alpbach in August 2017), participation at fairs (e.g. at Rapidtech2017), workshops (e.g. ERFAround in Leoben), and many publications, some of which are listed below. As far as academia is concerned, three $\mathrm{PhD}$ theses and six master's theses were completed, focussing on metallic components only. Two patents were submitted. Some more information is given on our website www.addmanu.at. In a joint action between ASMET and AIT, a roadmap for additive manufacturing is currently being prepared and will be available 2019. In February 2018, most of the participants of the "addmanu" leader project became members of the newly established Austrian platform "AM Austria" (www.am-austria.com).

It is worth mentioning that, due to this open knowledge transfer to scientists as well as to companies, additive manufacturing has entered into the curricula of Austrian universities and new business areas have been established in Austria. As a rough number, about 20 companies have in-
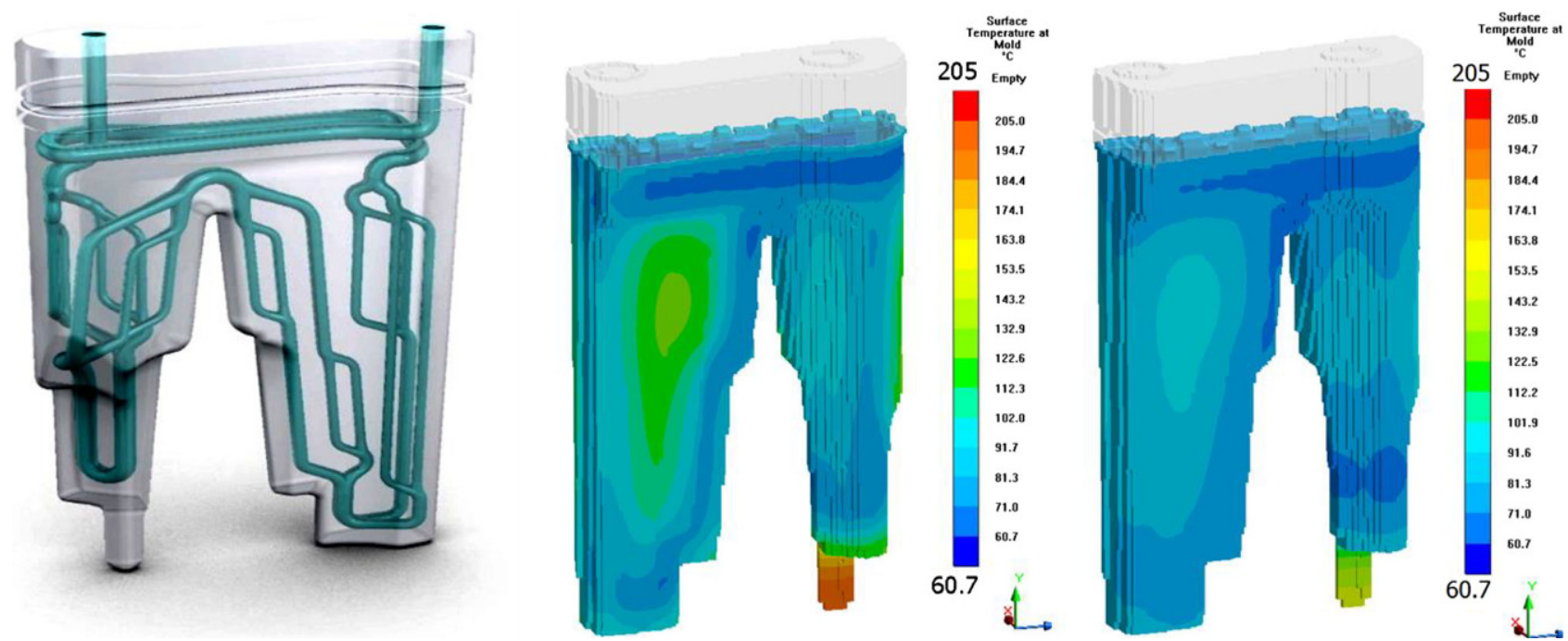

Fig. 10: Bionic inspired surface cooling of injection moulds - cooling channels and FEM temperature fields 
Fig. 11: CAD image and built prototype of an injection plate of a rocket motor (Fotec, Airbus Defense)
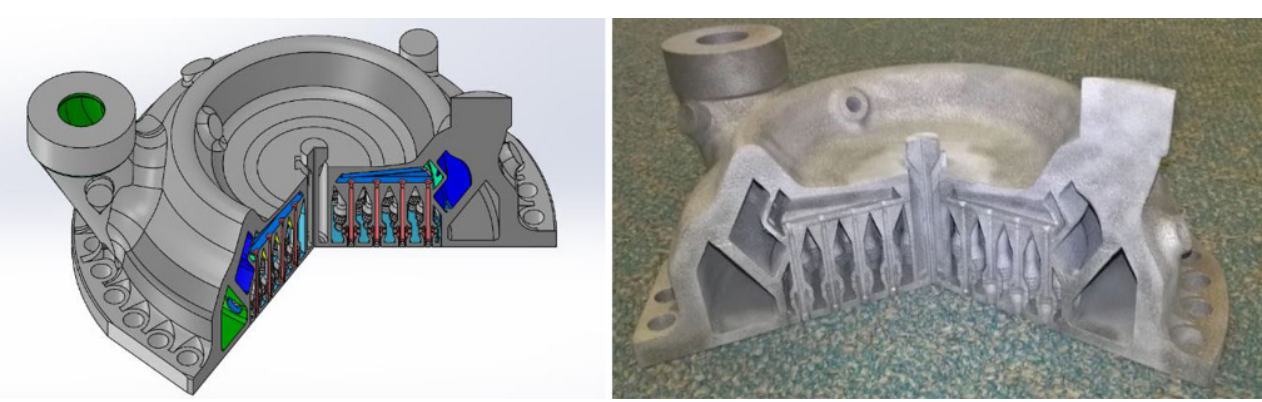

Fig. 12: Body for electronic parts, which need to be cooled very efficiently (RPH \& LUT/MUL)

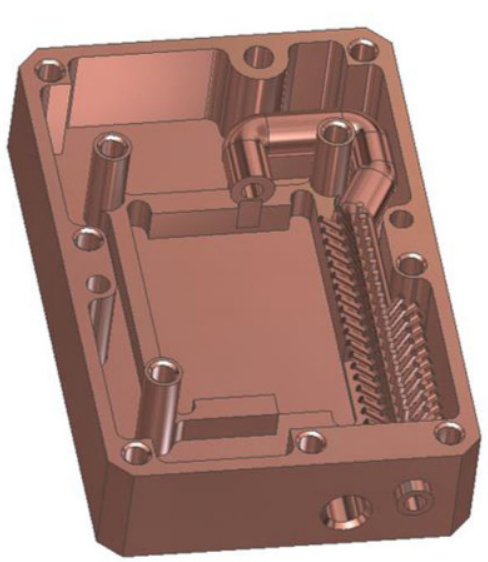

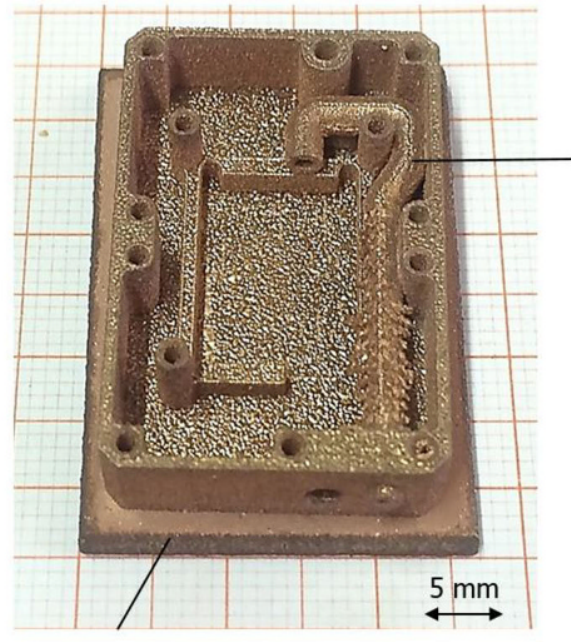

Cu-MMC vested in this new disruptive business field, which demonstrates the overall success of the leader project "addmanu".

\section{Conclusions}

The Austrian FFG leader project "addmanu" with about 20 partners was a great success not only for the participants but also for other interested companies, which could benefit from the knowledge and findings gained. Critical aspects for further use of the disruptive technology of selective laser melting could be clarified and new ideas for more projects could be obtained. The information of the most important findings were spread out in various forms in order to foster further developments in this field.

Finally, we would like to thank the Austrian research funding society FFG for their financial support.

Funding. Open access funding provided by Montanuniversität Leoben.

Open Access This article is distributed under the terms of the Creative Commons Attribution 4.0 International License (http://creativecommons. org/licenses/by/4.0/), which permits unrestricted use, distribution, and reproduction in any medium, provided you give appropriate credit to the original author(s) and the source, provide a link to the Creative Commons license, and indicate if changes were made.

Publisher's Note. Springer Nature remains neutral with regard to jurisdictional claims in published maps and institutional affiliations.

\section{References}

1. Gebhardt, A.: Additive Fertigungsverfahren: Additive Manufacturing und 3D-Drucken für Prototyping-Tooling-Produktion, 5. Auflage, München: Carl Hanser Verlag, 2016

2. Berger, U.; Hartmann, A.; Schmid, D.: 3D-Druck-Additive Fertigungsverfahren: Rapid Prototyping, Rapid Tooling, Rapid Manufacturing, Haan-Gruiten: Europa-Lehrmittel, 2. Aufl., 2017

3. Witt, G.; Wegner, A.; J. Sehrt, J.: Neue Entwicklungen in der Additiven Fertigung: Beiträge aus der wissenschaftlichen Tagung der Rapid.Tech 2015, Berlin, Heidelberg: Springer Vieweg, 2015

4. Kynast, M.; Eichmann, M. (Eds.): Rapid.Tech-Int. Trade Show \& Conf. for Additive Manufacturing, 20-22 June 2017, Erfurt, Germany, 2017

5. Richard, H. A.; Schramm, B.; Zipsner, T.: Additive Fertigung von Bauteilen und Strukturen, Wiesbaden: Springer Vieweg, 2017

6. Adam, G. A. O.: Systematische Erarbeitung von Konstruktionsregeln für die additiven Fertigungsverfahren Lasersintern, Laserschmelzen und Fused Deposition Modeling, Aachen: Shaker, 2015

7. Schmid, M.: Additive Fertigung mit Selektivem Lasersintern (SLS): Prozess- und Werkstoffüberblick, Wiesbaden: Springer Vieweg, 2016

8. Lachmayer, R.; Lippert, R. B.: Additive Manufacturing Quantifiziert, Berlin: Springer Verlag, 2017

9. Lachmayer, R.; Lippert, R. B.; Kaierle, S.: Additive Serienfertigung, Berlin: Springer Vieweg, 2018

10. Klahn, C.; Meboldt, M.; Federico, F; Leutenecker-Twelsiek, B.; Jansen, J.: Entwicklung und Konstruktion für die Additive Fertigung: Grundlagen und Methoden für den Einsatz in industriellen Endkundenprodukten, Würzburg: Vogel Business Media, 2018

11. Buchmayr, B.; Panzl, G.: Eine SWOT-Analyse zum Einsatz der Additiven Fertigung für metallische Bauteile, BHM, 160 (2015), no 1, pp 15-20 
12. Sames, W. J.; List, F. A.; Pannala, S.; Dehoff, R. R.; Babu, S. S.: The metallurgy and processing science of metal additive manufacturing, Int. Materials Reviews, 61 (2016), pp 315-360

13. Panzl, G.; Buchmayr, B.: Investigation of usability of plastic mould steels for the laser powder bed fusion process, Metal Additive Manufacturing Conf., 24.-25.Nov. 2016, Linz, Austria, 2016

14. Panzl, G.:The Application of Powder Rheology for AM Powders, MAMC2018, 21.-23.Nov: 2018, Wien, Austria, 2018

15. Buchmayr, B.; Panzl, G.; Walzl, A.; Wallis, C.: Laser Powder Bed Fusion-Materials issues and optimized processing parameters for tool steels, AISi10Mg, and CuCrZr-alloys, Advanced Engineering Materials, 19 (2017), no.4, pp 1600667

16. Wallis, C.; Buchmayr, B.; Kitzmantel, M.; Brandstätter, E.: Additive Manufacturing of Maraging Steel on a Copper substrate using Selective Laser Melting, Metal Additive Manufacturing Conference 2016, Linz, Austria, 2016

17. Wallis, C.; Buchmayr, B.; Kitzmantel, M.: Hybride Werkstoffsysteme mit komplexer 3D Struktur zur Fertigung von Hochleistungs-KühIkörper, Rapid.Tech Conference 2017, Erfurt, Germany, 2017
18. Wallis, C.; Buchmayr, B.: Effect of process parameters and heat treatments on microstructure and properties of Laser-Powder bed fused $\mathrm{CuCrZr}$-alloys, Alloys for Additive Manufacturing Symposium 2017, Dübendorf, Switzerland, 2017

19. Wallis, C.: 3D printed SLM Microchannels and Features in Copper integrating Diamond MMCs, 12th European Advanced Technology Workshop on Micropackaging and Thermal management, La Rochelle, France, 2017

20. Walzl, A.: Potentiale und Restriktionen von Gitterstrukturen für die additive Fertigung, PhD-Thesis, Lehrstuhl für Umformtechnik, Montanuniversität Leoben, Austria, 2018

21. Walzl, A.; Buchmayr, B.: Topology optimization-Design Tool for future manufacturing methods, Metal Additive Manufacturing Conf., 24.-25.Nov. 2016, Linz, Austria, 2016

22. Walzl, A.; Buchmayr, B.: Topologieoptimierung-Entwicklungswerkzeug für die additive Fertigung, BHM, 162 (2017), no 3, pp 110-116

23. Walzl, A.; Buchmayr, B.: Development of lattice structures and their application on automotive parts, Proc. XXXVI. Verformungskundl. Kolloquium, 18.-22.03.2017, Zauchensee, Austria, 2017 